\title{
Hindelang is not Hindu Kush. Military and Tradition
}

public-history-weekly.degruyter.com/6-2018-2/hindelang-not-hindukusch/

Demantowsky, Marko

January 25, 2018

- English

- Deutsch

Public History scandals have occurred repeatedly in the German Bundeswehr (German armed forces) in recent years. These scandals comprised young men belonging to this modern parliamentary army who actively draw on the traditions and symbols that were once used by the National Socialist Wehrmacht. This has prompted the German Ministry of Defence to consider a new "tradition legislature". How does it come to such scandals and what is their context? This article problematises this issue by touching on some fundamental questions: Why do people put on a uniform, submit themselves to strict regulations, endure hard training and drill, and in the end are prepared to kill other people or risk the possibility of their own death-if they don't have to?

\section{A Quick Bird's Historical Eye View}

Notwithstanding the admittedly Eurocentric nature of this sketch (please accept my apology for this), a retrospective look shows the change of motivations and reasons: In the ancient Greek polis it was an honour to be part of the phalanx as a hoplite and to enforce the interests of one's own polis against those of the competition. The Roman legionnaire, who also had to be a citizen, hoped for a share of the plunder or a piece of land after his time of service. A fighter for the auxiliary troops did the same and (later) also hoped for his civil rights. In the European "Middle Ages" reciprocal self-interest forced the nobleman to serve in the military allegiance, the motive of survival forced the citizen onto the battlements, or the legal dependency forced the country dweller into the squad of the landlord.

This changed when cities first began delegating the realisation of interests and the provision of protection to professionals: the Condottieri. This professional body caused a furore in the Early Modern Age; the Swiss mercenaries (Reis/äufer) were its best known experts. The risk was carried by individuals because the employment opportunities, unlike impoverishment in the local community were rated higher than the risk of injury or death. However, the loyalty within mercenary armies towards clients was limited.

As a result, modern armies were established first in the Netherlands, then in the modernising states of Early Modern Europe. They offered salaries, supplies, status (uniform) and opportunities for advancement, while at the same time regulating military violence - reason enough for many young men to enter such an army. Something like patriotism as a motive may already have become effective in the European Early Modern Age (e.g. in the context of the Orange Military Reform). In 
France, however, this factor was palpable after the fateful manifesto of the German Duke in 1792 and the Levée en masse of 1793. Belonging to a "nation" was now an obligation in an existential sense. The era of the modern national army with its conscripted military service declared the readiness for killing and being killed in uniforms as an achievement in collective identity. Later on, it extended to a "school of the nation" because it had moved far into the civilian sphere, and from there, to an initiation ritual of the modern (male) citizen as collective defence of one's own. That is what "Hindelang" stands for.[1]

This motivation was working across different times and systems of modernity: in democratic and dictatorial forms of rule, in open and closed societies (Popper). In each of these conscription armies there existed different propaganda structures to secure the existential loyalty of the young men-who were recruited mostly by force-, provided they had not previously been obscured too much by various nostrocentric myths. In the Bundeswehr of the old and new Federal Republic of Germany everything must of course be evaluated differently... There it is called "Innere Führung" ("internal leadership").

\section{Modern Armies after the Unipolar Moment}

The traditional modern system of motivating and securing the state-organised application and sustaining of violence, carried out and suffered in uniforms, had come to an end with the end of the Cold War. The unipolar moment.[2] No more enemy far and wide for the West. What was the use of having an army? The dividends of peace were being relished, military expenditure shrank, the number of soldiers was reduced. As a result, "military justice" came to be questioned, who was still to be drafted? The time of service was reduced, civil service was upgraded and became the dominant form of service. In the end, for young men there remained a period of several months of service for the common good (insofar as they were in the civil service). But what to do with the remaining army? The army that was meant to defend the "fatherland" was gradually deployed to what is termed somewhat obscurely "out of area". This meant that the deployment included areas outside of the German national territory, and even outside the NATO alliance territories.

In the 1990s and 2000s the change was fully accomplished: Volker Rühe's Somalia mission in 1993[3], Joseph Fischer's Auschwitz comparison in 1999[4], Peter Struck's Hindu Kush topos of 2002[5]-the new enemy was "international terrorism", and it had to be defeated on-site, which meant on many locations of this earth.[6] As such, the role of world-policing was assumed, which, up until then, had been carried out by old and new imperial powers of the USA, the UK, France and the Soviet Union / Russia without, however, communicating this openly. A German Federal President, who once took the liberty to do so, was criticised very harshly for doing so and consequently resigned from his office.[7]

\section{Making Sense at Hindu Kush}


It was Mr. Guttenberg, the Minister of Defence, who, in 2010, in the second cabinet of Angela Merkel, parallel to the affair with President Köhler, enforced the de facto abolition ("suspension") of compulsory military and and civil service in Germany.[8] Since then, a voluntary military service has been established. But the question remains, as it has been since the beginning of civilisation: Why should a young man, or (since 2001 in all areas) a young woman decide to commit to such a service? To fight the Taliban in Afghanistan? To control unruly tribes in Mali who are armed with weapons acquired from the overthrow of the Libyan government? To chase pirates near Somalia? It is unlikely that the old principles of the parliamentary army and internal leadership are made for these tasks. Or more precisely, they were never created for it.

The motivation for writing this article is the Bundeswehr scandals in recent years, in many of which Bundeswehr members explicitly drew on the traditions, symbols and persons associated with the National Socialist Wehrmacht.[9] I don't think that this accumulation of incidents in recent years is a coincidence, but that they can be explained by referring to the context outlined: Existential risks and limitations become acceptable if, a) the collective interest is regarded more highly (patriotism), or if b) the balance between risk and profit still seems favourable (as in the Early Modern Period). Whoever does not want to make the latter prominent because s/he can not give up the idea of defending Hindelang-automatically directs the reasoning to factor a). But whoever has nothing convincing to offer here, will accept that the old patterns of collective interests once again become a fixed point of orientation in time. For example, a British soldier draws on the military tradition of his country as an Empire, in which it is normal to fight "out of area". What is the connection for a German soldier? A reference to the nasty German imperial traditions is close at hand then.

\section{Negative Memory!}

Incidentally, it is fitting that the Bundeswehr recently acts like a normal employer and attracts new potential recruits at trade expos, at career exhibitions at school and universities, or in filmed commercials. It would be very interesting to see what kind of young men and women are attracted to this dangerous task and these restrictions to personal freedom.[10] An alternative solution seems to be outsourcing to the private sector.[11]

For me, the question remains open: Why and with what motivation should a German citizen in a uniform make use of his or her weapon at the Hindu Kush or off the coast of Lebanon? What could be motivating him or her, other than money, adventure, prestige? Why should the government invest such tax money, if not to pursue tangible interests? It seems important and urgent for me to get clarity on this, so that the wrong search for patriotic reasons and historical traditions does not keep ending up in embarrassing scandals. You cannot pretend, without a cost, that you still have the old national territorial army of the Cold War, and at the same time use the military infrastructure for worldwide deployment. These are imperial uses - integrated into the 
Western Alliance. President Köhler was right when, in 2005, he was honest and put national "interests"[12] at the centre of this debate. The 2010 interview[13] only made it clearer. This debate needs to continue.

Historically, and according to the pattern of the national territorial army, there is no longer making any loyalty here. The solution could lie in realising the European perspective. Nevertheless, imperial historical reminiscences would be fatal here too. Consistent would be a combination of a negative foundation of tradition (cf. Knigge) [14] and the open articulation of interests.

"Von der Leyen orders distance to the Wehrmacht and the NVA"[15], if it were possible par ordre du mufti!

And what about Hindelang? Well, we now have Putin (but that is another issue).

\section{Further Reading}

- Münkler, Herfried. Die neuen Kriege. Reinbek bei Hamburg: Rowohlt, 2002.

- Wolfrum, Edgar. Rot-Grün an der Macht. München: Beck, 2013.

- Reichenberger, Florian. Der gedachte Krieg. Vom Wandel der Kriegsbilder in der Bundeswehr. München: De Gruyter Oldenbourg, 2018 (in press).

\section{Web Resources}

- Official YouTube Channel of the German Bundeswehr (last accessed 19 January 2018).

- Official Instagram Account of the German Bundeswehr (last accessed 19 January 2018).

- German Ministry of Defense. History of the Bundeswehr (last accessed 19 January 2018).

I thank Matthias Krämer for the editorial support.

[1] Bad Hindelang is a pretty 5000-population small town in the Oberallgäu (Bayern) (Wikipedia, last edit 11 Jan 2018, 9h57), which, due to its linguistic proximity to the Central Asian high mountains, was made a symbol of German territorial defence by the then Federal Minister of Defense, Peter Struck, in a famous debate in the Bundestag. Cf. Deutscher Bundestag. Stenografischer Bericht 97. Sitzung, Berlin, Donnerstag, 11. März 2004, p. 8601 (last accessed 19 January 2018).

[2] Krauthammer, Charles. “The Unipolar Moment”. In Foreign Affairs, 70(1990/91), No 1, pp. 23-33.

[3] Wikipedia-Lemma: “United Nations Operation in Somalia II” (last edit 26 Jan 2017, 16h47).

[4] "Wortlaut. Auszüge aus der Fischer-Rede". In Der Spiegel 13 May 1999 (last accessed 19 January 2018). For contextualization cf. Wolfram, Edgar. Rot-Grün an der Macht. München: Beck, 2013, pp. 64-109.

[5] The topos was probably endeavoured for the first time at a press conference in 2002 by the then Minister of Defence Peter Struck. Cf. Clement, Rolf: “Verteidigung am Hindukusch in Afghanistan”. In Deutschlandfunk, 22.12.2011 (last accessed 19 January 2018).

[6] Homepage of the Federal Ministry of Defense. "Die Auslandseinsätze der Bundeswehr" (last accessed 19 January 2018).

[7] Erklärung von Bundespräsident Horst Köhler, Schloss Bellevue, 31 May 2010 (last accessed 19 January 2018). 
[8] "Wie Guttenberg die Wehrpflicht abschaffte. Sechs Monate für das Undenkbare". In Süddeutsche Zeitung, 16 May 2011 (last accessed 19 January 2018).

[9] Just a reminder, here are a few examples:

- 2017: “Bundeswehr-Skandale ohne Ende?" In NDR info, 5 May 2017 (last accessed 19 January 2018).

- 2016: Leonhard, Ralf. "Abwehrkampf gegen das Hakenkreuz. Bundeswehr und Social Media". In: taz, 1 December 2016 (last accessed 19 January 2018).

- 2012: Jansen, Frank und Christian Tretbar. "Die Braunen in Oliv. MAD-Mitarbeiter rügt früheren Umgang der Bundeswehr mit Rechtsextremen“. In Der Tagesspiegel, 9 November 2012 (last accessed 19 January 2018). [10] "Bundeswehr. Jeder vierte einfache Soldat hat Migrationshintergrund". In Frankfurter Allgemeine Zeitung, 3. Juli 2016 (source Bild am Sonntag), (last accessed 19 January 2018). One does not only see the pattern of the old imperial army, but even that of the old Reisläufer (Swiss early modern mercenaries). The Condottierri is also available again. Cf. Schimmeck, Tom. "Privatisierter Krieg. Die Rückkehr der Söldner". In

Deutschlandfunk, 31 May 2015 (last accessed 19 January 2018). It is well known that the US Army and the Russian Army systematically involve private non-state troops in their operations. German mercenaries, however, officially do not exist (cf. ibid.), in Germany their recruitment is punishable by law (vgl.StGB § 109, (last accessed 19 January 2018). However, reports of German mercenaries have not only been around since the wars in Yugoslavia in the 1990s.

[11] Fuchs, Christian und Hause Friedrichs. "Bundeswehr. Private Söldner unterwandern die Truppe“. In Die ZEIT, 10 September 2016 (last accessed 19 Jan 2018).

[12] "Rede von Bundespräsident Horst Köhler bei der Kommandeurtagung der Bundeswehr in Bonn, 10. Oktober 2005". In Deutsches Bundespräsidialamt, without date (last accessed 19 January 2018).

[13] "Rücktritt von Köhler. Das umstrittene Interview im Wortlaut". In Süddeutsche Zeitung, 31 May 2010 (last accessed 19 January 2018).

[14] In short, it is about the fact that, in perspective on the Holocaust and the other crimes committed by the Germans in the German Nazi state for today's Federal Republic, collective identity could come from the prevention of everything that Nazi rule made possible. Never again as a basic motive. Cf. Knigge, Volkhardt. "Zur Zukunft der Erinnerung". In Aus Politik und Zeitgeschichte (2010) 25/26, pp. 10-16.

[15] Funny you think you have to involve the NVA. For a long time, there has been no mention of any links to the GDR army. Cf. Gebauer, Matthias. “Neuer Bundeswehr-Erlass. Von der Leyen ordnet Distanz zu Wehrmacht und NVA an“. In Der Spiegel, 20 November 2017 (last accessed 19 January 2018).

Image Credits

German Soldiers in Afghanistan, 6 Dezember 2012. Source and further information. Lizenz CC-BY-ND 2.0

Recommended Citation

Demantowsky, Marko: "Hindelang is not Hindu Kush. Military and Tradition”. In Public History Weekly, 6 (2018)

2, DOI: $\underline{\mathrm{dx} . \text { doi.org/10.1515/phw-2018-10910 }}$

Translated from German by Dr Katalin Morgan. (katalin.morgan (at) uni-due (dot) de)

Editorial Responsibility

\section{Dominika Uczkiewicz / Krzysztof Ruchniewicz}

Copyright (c) 2018 by De Gruyter Oldenbourg and the author, all rights reserved. This work may be copied and redistributed for non-commercial, educational purposes, if permission is granted by the author and usage right holders. For permission please contact: elise.wintz (at) degruyter.com.

In der deutschen Bundeswehr haben sich in den vergangenen Jahren immer wieder PublicHistory-Skandale ereignet. Diese Skandale bestanden darin, dass junge Männer dieser modernen Parlamentsarmee sich aktiv auf Traditionen und Symbole der nationalsozialistischen Wehrmacht bezogen haben. Das hat das deutsche Verteidigungsministerium jüngst dazu veranlasst, einen neuen "Traditionserlass" zu 
erwägen. Wie kommt es zu diesen Skandalen, was ist ihr Kontext? Hier ein Problemaufriss, der grundsätzliche Fragen berührt: Warum zieht man sich eine Uniform über, unterwirft sich einem strengen Reglement, erträgt hartes Training und Drill und ist am Ende bereit dazu, andere Menschen zu töten oder seinen eigenen Tod in Kauf zu nehmen - wenn man es nicht muss?

\section{Im Parforceritt nach Hindelang}

Ein Blick zurück zeigt einen Wandel von Motivationslagen und Begründungen (man vergebe mir die grobe, eurozentrische Skizze): In der altgriechischen Polis war es eine Ehre, als Hoplit Teil der Phalanx zu sein und den Interessen der eigenen Polis gegenüber der Konkurrenz Geltung zu verschaffen. Der römische Legionär, der auch Bürger sein musste, erhoffte sich einen Anteil Beute oder ein Stück Land nach der Dienstzeit, ein Kämpfer der Hilfstruppen das Gleiche plus (später) das Bürgerrecht. Im europäischen "Mittelalter" zwang wechselseitiges Eigeninteresse den Adligen in die militärische Gefolgschaft, das Überlebensmotiv den Bürger auf die Zinnen oder die rechtliche Abhängigkeit den Landbewohner in die Truppe des Grundherrn.

Das änderte sich, als zuerst Städte begannen, Interessenswahrnehmung und Schutz an Profis zu delegieren: die Condottieri. Dieses Profitum machte in der Frühen Neuzeit Furore, die Schweizer Reisläufer waren seine bekanntesten Experten. Als einzelner nahm man das Risiko auf sich, weil die Erwerbs-Chancen im Gegensatz zur Verarmung in der heimischen Gemeinde als höher bewertet wurden als die Gefahr von Verletzung oder Tod. Die Loyalität in Söldnerheeren gegenüber Auftraggebern war allerdings beschränkt.

Erst in den Niederlanden, dann in den sich modernisierenden Staaten des frühneuzeitlichen Europa begann man unter anderem deshalb mit der Aufstellung stehender Heere: Man bot Sold, Versorgung, Ansehen (Uniform) und Aufstiegschancen bei gleichzeitiger Regulation der militärischen Gewalt, Grund genug für viele junge Männer, in eine solche Armee einzutreten. So etwas wie Patriotismus als Motiv mag in der europäischen Frühen Neuzeit schon auch andernorts wirksam geworden sein (etwa im Kontext der Oranischen Heeresreform). Mit Händen zu greifen ist dieser Faktor aber in Frankreich nach dem verhängnisvollen Manifest des deutschen Herzogs 1792 und der Levée en masse von 1793. Die Zugehörigkeit zu einer "Nation" verpflichtete nun existentiell. Das Zeitalter der modernen Nationalarmee mit allgemeiner Wehrpflicht erklärte die Bereitschaft zum uniformierten Töten und Getötetwerden zu einer großgruppenbezogenen Identifikationsleistung, später zu einer, weit ins Zivile übergreifend, "Schule der Nation", zum Initiationsritual des modernen (männlichen) Staatsbürgers als kollektiver Verteidigung der/des Eigenen: dafür steht "Hindelang".[1]

Diese Motivation hat über unterschiedliche Zeiten und Systeme der Moderne hinweg funktioniert: in demokratischen wie diktatorischen Herrschaftsformen, offenen und geschlossenen Gesellschaftsformen (Popper). In diesen Wehrpflichtarmeen existierten jeweils verschiedene Propagandastrukturen, um die existentielle Loyalität der größtenteils zwangsrekrutierten jungen Männer zu sichern, sofern diese nicht schon 
vorab von den diversen nostrozentrischen Mythen hinreichend vernebelt waren. In Bezug auf die Bundeswehr der alten und neuen Bundesrepublik Deutschland muss das natürlich alles ganz anders bewertet werden, dort nennt man das "Innere Führung".

\section{Moderne Armeen nach dem unipolaren Moment}

Das herkömmliche moderne System der Motivationsstiftung und -sicherung für staatlich organisiertes uniformiertes Gewaltanwenden und -ertragen war mit dem Ende des Kalten Krieges an sein Ende gelangt. Der unipolare Moment.[2] Kein Feind mehr weit und breit für den Westen. Wozu noch Armeen? Die Friedensdividende wurde genossen, die Rüstungsausgaben schrumpften, die Zahl der Soldaten wurde reduziert. In der Folge geriet die "Wehrgerechtigkeit" in Frage, wer wurde noch eingezogen? Man reduzierte die Dienstzeit, wertete den Zivildienst auf, der zur dominanten Einsatzform aufstieg, am Ende blieb für junge Männer eine mehrmonatige Phase der Dienstpflicht am Gemeinwohl (sofern im Zivildienst). Aber wohin mit der Restarmee? Aus einer Vaterlandsverteidigungsarmee wurde schrittweise eine Armee im Einsatz, und zwar, wie es so schön vernebelnd auf Englisch hieß: "Out of area”. Das bedeutete, dass der Einsatz außerhalb des deutschen Staatsgebietes, sogar außerhalb des NATO-Bündnisgebietes stattfand.

In den 1990er und 2000er Jahren vollzog sich der Wandel: Volker Rühes SomaliaEinsatz 1993,[3] Joseph Fischers Auschwitz-Vergleich 1999,[4] Peter Strucks Hindukusch-Topos von 2002[5] - der neue Feind war der internationale Terrorismus, der vor Ort, und zwar an sehr vielen Stellen auf dieser Erde,[6] bekämpft werden müsse. Man übernahm damit gleichsam weltpolizeiliche Aufgaben, die bis dahin die alten und neuen Imperialmächte USA, UK, Frankreich und Sowjetunion/Russland getragen hatten - ohne dies aber offen zu kommunizieren. Ein deutscher Bundespräsident, der sich einmal die Freiheit dazu nahm, wurde sehr hart kritisiert und hat daraufhin seinen Hut genommen.[7]

\section{Sinnstiftung am Hindukusch?}

Es war ein Herr Guttenberg als Verteidigungsminister, der 2010, im zweiten Kabinett Merkel, parallel zur Affäre Köhler, die faktische Abschaffung ("Aussetzung") der Wehrund Wehrersatzpflicht in Deutschland durchsetzte.[8] Seitdem gibt es die Einrichtung des freiwilligen Militärdienstes in der Bundesrepublik. Die Frage stellt sich aber wie seit dem Beginn der Zivilisation: Warum soll einer junger Mann oder (seit 2001 in allen Bereichen) eine junge Frau diesen Dienst auf sich nehmen? In Afghanistan Taliban bekämpfen? Im Mali renitente Stämme, die sich mit Waffen aus dem Sturz der libyschen Regierung ausgerüstet haben? Vor Somalia Piraten jagen? Für diese Aufgaben scheinen die alten Grundsätze der Parlamentsarmee und der Inneren Führung nicht gemacht zu sein. Oder genauer: Sie wurden nicht dafür geschaffen.

Der Anlass des Artikels sind die Bundeswehrskandale der letzten Jahre, von denen viele darin bestanden, dass Angehörige der Bundeswehr sich explizit auf Traditionen, Symbole und Personen der nationalsozialistischen Wehrmacht bezogen haben.[9] Ich 
glaube, dass diese Häufung in den letzten Jahren kein Zufall ist, sondern sich aus dem skizzierten Kontext erklären lässt:

Existentielle Risiken und Einschränkungen werden akzeptabel, wenn a) das Kollektivinteresse höher gesichtet wird (Patriotismus) oder wenn b) die Balance aus Risiko und Gewinn immer noch günstig erscheint (wie in der Frühen Neuzeit). Wer letzteres nicht prominent machen möchte, weil er die Idee der Verteidigung Hindelangs nicht aufzugeben vermag, der lenkt die Begründung automatisch auf Faktor a. Wer dann aber wiederum hier nichts Überzeugendes anzubieten hat, der nimmt in Kauf, dass alte Muster von Kollektivinteresse wieder zum Fixpunkt der Orientierung in der Zeit werden. Ein z.B. britischer Soldat steht in der militärischen Tradition seines Landes als Empire, in dem es als normal gilt, “out of area” zu kämpfen. Woran knüpft ein deutscher Soldat oder eine deutsche Soldatin an? Ein Bezug auf die üblen deutschen imperialen Traditionen liegt dann nahe.

\section{Negatives Gedächtnis!}

Es passt im Übrigen in diese Lage, dass die Bundeswehr neuerdings wie ein normaler Arbeitgeber auftritt und auf Berufsmessen, an Berufsschulen, an Hochschulen oder in Werbefilmen um neue RekrutInnen wirbt. Es wäre sehr interessant, welche jungen Männer und Frauen sich von dieser gefährlichen Aufgabe und dieser Einschnitten in die persönliche Freiheit angezogen fühlen.[10] Ein Alternativlösung scheint das Outsourcing an Private zu sein.[11]

Die Frage bleibt für mich offen: Warum und mit welcher Motivation soll einE deutscheR StaatsbürgerIn in Uniform am Hindukusch oder vor der Küste des Libanon von seiner Waffe Gebrauch machen? Was soll sie/ihn anderes motivieren als Geld, Abenteuer, Prestige? Warum soll der Bundestag diese Steuermittel investieren, wenn nicht aus handfesten Interessen? Es erscheint mir wichtig und dringend, sich das klar zu machen, damit nicht die falsche Suche nach patriotischen Gründen und historischen Traditionen weiterhin in peinliche Skandale mündet. Man kann nicht ohne Kosten so tun, als ob man die alte Landesverteidigungsarmee des Kalten Krieges noch hätte, gleichzeitig aber die militärische Infrastruktur auf weltweiten Einsatz ausrichten. Es sind imperiale Verwendungen - eingebunden in das westliche Bündnis. Bundespräsident Köhler hatte recht, als er schon 2005 ehrlicherweise nationale "Interessen"[12] in den Mittelpunkt dieser Debatte gerückt hat. Das Interview von 2010[13] hat es nur deutlicher formuliert. Diese Debatte muss weitergehen.

Historisch und nach dem Muster einer nationalen Territorialarmee ist hier keine Loyalität mehr zur stiften. Die Lösung könnte in Realisierung der europäischen Perspektive liegen. Imperiale historische Reminiszenzen wären aber auch hier fatal. Konsequent wäre eine Verbindung von negativer Traditionsstiftung (im Sinne Knigges) [14] und offener Interessensartikulation.

"Von der Leyen ordnet Distanz zu Wehrmacht und NVA an",[15] ... wenn das doch nur par ordre du mufti ginge! 
Und was wird aus Hindelang? Wir haben ja jetzt Putin. Aber das ist eine andere Geschichte.

\section{Literaturhinweise}

- Münkler, Herfried. Die neuen Kriege. Reinbek bei Hamburg: Rowohlt, 2002.

- Wolfrum, Edgar. Rot-Grün an der Macht. München: Beck, 2013.

- Reichenberger, Florian. Der gedachte Krieg. Vom Wandel der Kriegsbilder in der Bundeswehr. München: De Gruyter Oldenbourg, 2018 (im Druck).

\section{Webressourcen}

- Offizieller YouTube Channel der Deutschen Bundeswehr (letzter Zugriff: 19.01.2018).

- Offizieller Instagram Account der Deutschen Bundeswehr (letzter Zugriff: 19.01.2018).

- Bundesministerium für Verteidigung. Geschichte der Bundeswehr (letzter Zugriff: 19.01.2018).

Ich danke Matthias Krämer für die redaktionellen Hinweise.

[1] Bad Hindelang ist ein hübsches 5000-Einwohnerlnnen-Städtchen im Oberallgäu (Bayern) (Wikipedia, letzte Änderung v. 11.1.2018, 9:57 Uhr), das wegen seiner sprachlichen Nähe zum mittelasiatischen Hochgebirge vom damaligen Bundesverteidigungsminister Peter Struck in einer berühmt gewordenen Bundestagsdebatte zum Symbol der deutschen Territorialverteidigung gemacht worden ist. Vgl. Deutscher Bundestag. Stenografischer Bericht 97. Sitzung, Berlin, Donnerstag, 11. März 2004, BI. 8601 (letzter Zugriff: 19.01.2018).

[2] Krauthammer, Charles. "The Unipolar Moment". In Foreign Affairs, 70(1990/91), No 1, pp. 23-33.

[3] Wikipedia-Lemma: “United Nations Operation in Somalia II’ (letzte Änderung am 26. Januar 2017, 16:47 Uhr).

[4] "Wortlaut. Auszüge aus der Fischer-Rede". In Der Spiegel 13. Mai 1999 (letzter Zugriff: 19.01.2018). Zur Einordnung vgl. Wolfram, Edgar. Rot-Grün an der Macht. München: Beck, 2013, pp. 64-109.

[5] Der Topos wurde wohl erstmals auf einer Pressekonferenz 2002 vom damaligen

Bundesverteidigungsminister Peter Struck bemüht. Vgl. Clement, Rolf: "Verteidigung am Hindukusch in Afghanistan“. In Deutschlandfunk, 22.12.2011 (letzter Zugriff: 19.01.2018).

[6] Homepage des Bundesministeriums für Verteidigung. "Die Auslandseinsätze der Bundeswehr" (letzter Zugriff: 19.01.2018).

[7] Erklärung von Bundespräsident Horst Köhler, Schloss Bellevue, 31. Mai 2010 (letzter Zugriff: 19.01.2018).

[8] "Wie Guttenberg die Wehrpflicht abschaffte. Sechs Monate für das Undenkbare". In Süddeutsche Zeitung,

16. Mai 2011 (letzter Zugriff: 19.01.2018).

[9] Nur zur Erinnerung, ein paar Beispiele:

- 2017: “Bundeswehr-Skandale ohne Ende?" In NDR info, 5 May 2017 (letzter Zugriff: 19.01.2018).

- 2016: Leonhard, Ralf. "Abwehrkampf gegen das Hakenkreuz. Bundeswehr und Social Media“. In: taz, 1 December 2016 (letzter Zugriff: 19.01.2018).

- 2012: Jansen, Frank und Christian Tretbar. “Die Braunen in Oliv. MAD-Mitarbeiter rügt früheren Umgang der Bundeswehr mit Rechtsextremen“. In Der Tagesspiegel, 9 November 2012 (letzter Zugriff: 19.01.2018). [10] "Bundeswehr. Jeder vierte einfache Soldat hat Migrationshintergrund". In Frankfurter Allgemeine Zeitung, 3. Juli 2016 (Quelle: Bild am Sonntag),(letzter Zugriff: 19.01.2018).Man sieht nicht nur das Muster der alten Imperialarmee wieder aufziehen, sondern sogar das der alten Reisläufer. Auch die Condottierri gibt es wieder. Vgl. Schimmeck, Tom. “Privatisierter Krieg. Die Rückkehr der Söldner". In Deutschlandfunk, 31. Mai 
2015 (letzter Zugriff: 19.01.2018).Dass die US Army und die russische Armee systematisch nicht-staatliche Privattruppen in ihre Operationen einbeziehen, ist bekannt. Deutsche Söldner gibt es aber offiziell nicht (vgl. ebd.), ihre Anwerbung ist strafbar (vgl. StGB § 109 (letzter Zugriff: 19.01. 2018). Berichte über deutsche Söldner gibt es nicht erst set den Jugoslawienkriegen der 1990er Jahre.

[11] Fuchs, Christian und Hause Friedrichs. "Bundeswehr. Private Söldner unterwandern die Truppe". In Die ZEIT, 10 September 2016 (letzter Zugriff: 19.01.2018).

[12] "Rede von Bundespräsident Horst Köhler bei der Kommandeurtagung der Bundeswehr in Bonn, 10. Oktober 2005“. In Deutsches Bundespräsidialamt, ohne Datum (letzter Zugriff: 19.01.2018).

[13] "Rücktritt von Köhler. Das umstrittene Interview im Wortlaut". In Süddeutsche Zeitung, 31. Mai 2010 (letzter Zugriff: 19.01.2018).

[14] Knigge, Volkhardt. "Zur Zukunft der Erinnerung". In Aus Politik und Zeitgeschichte (2010) 25/26, pp. 1016.

[15] Lustig, dass man glaubt, die NVA miteinbeziehen zu müssen. Von Anknüpfungen an die DDR-Armee hat man lange nichts gehört. Vgl. Gebauer, Matthias. "Neuer Bundeswehr-Erlass. Von der Leyen ordnet Distanz zu Wehrmacht und NVA an". In Der Spiegel, 20. November 2017 (letzter Zugriff: 19.01.2018).

Abbildungsnachweis

Deutsche Soldaten in Afghanistan, 6. Dezember 2012. Quelle und weitere Angaben. Lizenz CC-BY-ND 2.0

Empfohlene Zitierweise

Demantowsky, Marko: "Hindelang ist nicht Hindukusch. Militär und Tradition". In Public History Weekly 6 (2018) 2, DOI: $\underline{\text { dx.doi.org/10.1515/phw-2018-10910. }}$.

Redaktionelle Verantwortung

Dominika Uczkiewicz / Krzysztof Ruchniewicz

Copyright (c) 2018 by De Gruyter Oldenbourg and the author, all rights reserved. This work may be copied and redistributed for non-commercial, educational purposes, if permission is granted by the author and usage right holders. For permission please contact: elise.wintz (at) degruyter.com.

\section{Mehr und hoffentlich Kontroverses zu diesem Thema}

\section{am 1. Februar, 20 Uhr, in der nächsten Sendung des "Geschichtstalk im Super7000".}

Ein Projekt der Gerda Henkel Stiftung (Düsseldorf) und der Professur Gesellschaftswissenschaften und ihre Disziplinen an der PH FHNW (Basel/BruggWindisch) in Kooperation mit der Verband der Historiker und Historiker Deutschlands (VHD)

- Hier kommen Sie zum Livestream.

- Der YouTube Channel der Sendung

Categories: $\underline{6(2018) 2}$

DOI: dx.doi.org/10.1515/phw-2018-10910

Tags: Germany (Deutschland) Identity (Identität), Military (Militär) 